
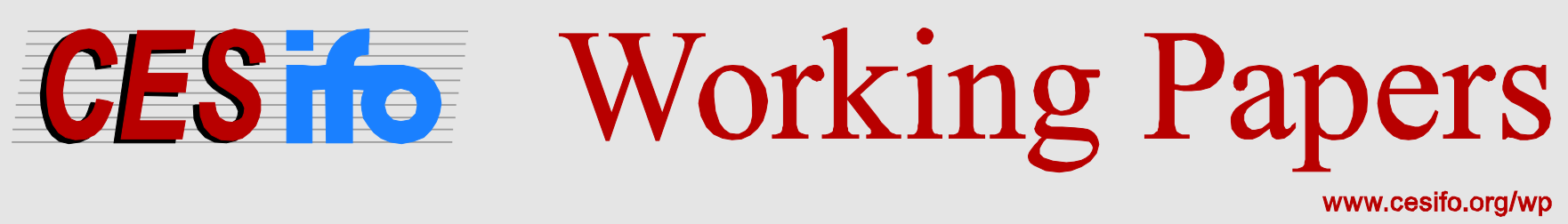

\title{
Efficiency, Fairness, and Social Cohesion in Europe and the United States: Incomes, Hours of Work, and Equality with an Afterthought on Iceland
}

\author{
Thorvaldur Gylfason
}

CESIFO WORKING PAPER NO. 6025

CATEgory 2: Public Choice

August 2016

An electronic version of the paper may be downloaded

- from the SSRN website:

- from the RePEc website:

- from the CESifo website:

wWw.SSRN.com

www.RePEc.org

www.CESifo-group.org/wp 


\title{
Efficiency, Fairness, and Social Cohesion in Europe and the United States: Incomes, Hours of Work, and Equality with an Afterthought on Iceland
}

\begin{abstract}
The paper discusses the European Union as a union of primarily small European states, a union whose parallel emphasis on efficiency and fairness, including deep respect for human rights, holds the key to Europe's economic and social advances over the years. The paper shows that adjusting conventional economic indicators of living standards such as gross domestic product or gross national income per capita to reflect also social factors (such as hours of work and equality of income) places Europe ahead of the United States. Further, adjustments for education attainment and public health, as made by the United Nations Human Development Index, similarly favor Europe vis-à-vis the US. While expansion fatigue has temporarily slowed the momentum of the widening and deepening of European integration, Europe can expect to benefit from the accession of more small states to the EU. This will further advance the EU's economic and social position in the world.
\end{abstract}

Keywords: efficiency, hours worked, equality, social capital, European Union, United States.

\author{
Thorvaldur Gylfason \\ Department of Economics \\ University of Iceland \\ Scemundargata 2 \\ Iceland - 101 Reykjavík \\ gylfason@hi.is
}

28 July 2016

The paper is intended to reflect my personal belief that too few economists and others seem to care to defend the European ideal against its emerging detractors. In this spirit, the paper was presented at the 28th Villa Mondragone International Economic Seminar on the theme "Facing EU Challenges, Relaunching Sustainable Growth” in Rome, 23-24 June 2016. I wish to thank Magnús Bjarnason, Eduard Hochreiter, Arne Jon Isachsen, Ólafur Ísleifsson, Gylfi Magnússon, Jeffrey Sachs, and especially Per Magnus Wijkman for helpful comments on earlier versions of the text. 


\section{Introduction}

Despite well-known shortcomings, gross national income (GNI) or gross domestic product (GDP) per capita remains the most commonly used indicator of macroeconomic performance. By this measure, the United States was for a long time the undisputed frontrunner of the world economy, surpassed only recently by a few small countries that became rich due to their oil wealth such as Kuwait and Norway or their financial prowess such as Luxembourg. Convention and easy availability appear to be the main reasons for the continued emphasis on per capita GNI or GDP in macroeconomic policy analysis.

It became clear some time ago that GNI and GDP at market prices and exchange rates tend to significantly overstate the income differences between rich countries and poor countries because prices are generally lower in poor countries than in rich ones. Consequently, adjustments for purchasing power were promptly made. The Penn World Tables adjust national accounts country by country in their own currencies by using detailed price data to produce real national accounts in a common currency (US dollars), covering 182 countries from 1950 to 2014. Even so, PPP-adjusted national accounts data as reported by the World Bank and the IMF reach back only to 1990. Thus the first 30 years of national income data that generally go back at least to 1960 in most countries reporting to the World Bank and the IMF are not PPP-adjusted.

To improve their national accounts, countries such as Italy have made adjustments for home production and the informal economy (Feige, 1979; Schneider and Enste, 2000; Schneider, 2007). Internationally comparable green national accounts taking environmental degradation into consideration remain to see the light of day. Even so, the World Bank (2006) has made significant progress toward the measurement of different kinds of capital, including natural capital, human capital, and social capital, with a view to adjusting the national accounts describing income flows to permit adjustments for changes in national assets and liabilities. It is an old story: stocks matter for flows and vice versa.

This is a key point for measuring macroeconomic welfare. If two countries have identical incomes but one of them runs down its national assets (natural environment or resources, human capital, societal institutions, public trust, you name it) or piles up foreign debts, then the country that keeps its national assets and liabilities on an even keel is clearly in a 
stronger economic position even if national accounts fail to chart the difference. In other words, sustainable development matters.

In general, as stressed by Stiglitz, Sen, and Fitoussi (2010) and Deaton (2013), among others, economic and social indicators need to be viewed side by side to provide a clear picture of a country's economic standing. One dimension alone is not enough. If two countries have the same per capita income but one of them is able to offer its people better education and longer lives, then the latter country is clearly better off on balance. This is the key idea behind the United Nations Human Development Index that weighs incomes, education, and health in equal proportions to produce a broader index of the standard of life than income alone would do. This has always been considered obvious in the field of finance where no one would consider judging an asset solely by its return because assets need to be assessed in two dimensions: by their return as well as the associated risk.

This principle applies also to macroeconomics (Gylfason, 2007). In this paper, we judge a nation's economy not only by the incomes generated by its people - or, if you prefer, by the consumption those incomes make possible - but also by the distribution of the nation's income and consumption across the population as measured, for example, by the Gini index. As an empirical matter as well as in theory, this index closely correlated with common measures of dispersion such as the standard deviation of the variable in question around its mean. Yet another feature often left out of international comparisons of economic performance is diversification and complexity. If two economies are identical except one is well diversified and offers complex - e.g., high-tech - products for sale to its trading partners and the other does not, then, on balance, the diversified and complex economy is better off. The argument can be extended to various aspects of social capital, including corruption in business and politics and lack of trust.

This paper offers a comparison of Europe and the United States by reviewing some current economic and social indicators. It starts by considering the Group of Eight (G8) countries, i.e., G7 plus Russia: Canada, France, Germany, Italy, Japan, Russia, the United Kingdom, and the United States. It thereafter extends the analysis to include a number of smaller European countries. Specifically, the paper emphasizes the comparison of the purchasing power of national income per hour worked rather than per capita. This matters because different nations have exploited rising labor productivity and living standards in 
different ways. Some have preferred rapidly rising incomes combined with slowly reduced work effort while others have preferred less rapidly rising incomes in conjunction with significantly less work - that is, increased leisure. Income per hour worked is a better measure of the standard of life than income per person because income per hour worked reflects the effort behind the income earned. Most people might prefer unchanged income combined with less work if they were free to choose. All nations want higher output/input ratios but different people and nations may differ in their preference for increased output vis-à-vis reduced input, including work. Thereafter, the paper makes adjustments for inequality and includes social measures such as education and health.

The paper is organized as follows. A comparison of broad measures of the standard of life is offered in Section II, suggesting that the United States has fallen behind Europe's four largest countries, especially when inequality and social measures of welfare are considered. Section III extends the cross-country comparisons to include smaller and more homogeneous EU nations. We contend that these tend to pay more attention to fairness and equality than larger nations and, therefore, that the EU may well benefit from the accession of more small members. Section IV briefly discusses some of the current difficulties confronting the EU. Section V takes up the special case of Iceland and its position vis-à-vis the EU. Section VI reviews the main points made.

\section{Incomes per Person and per Hours Worked in the G8}

We start by showing data on the purchasing power of income per person (Chart 1) and of income per hour worked (Chart 2) in the G8 countries in 1990 and 2014 side by side. These figures can be viewed as indicators of long-term growth because a country's income level today reflects past growth. Chart 1 shows that the US led the G8 countries in terms of GNI per capita in 1990 and continued to do so in 2014. 


\section{Chart 1. G8 countries: GNI per capita 1990 and 2014 (Current USD, PPP)}

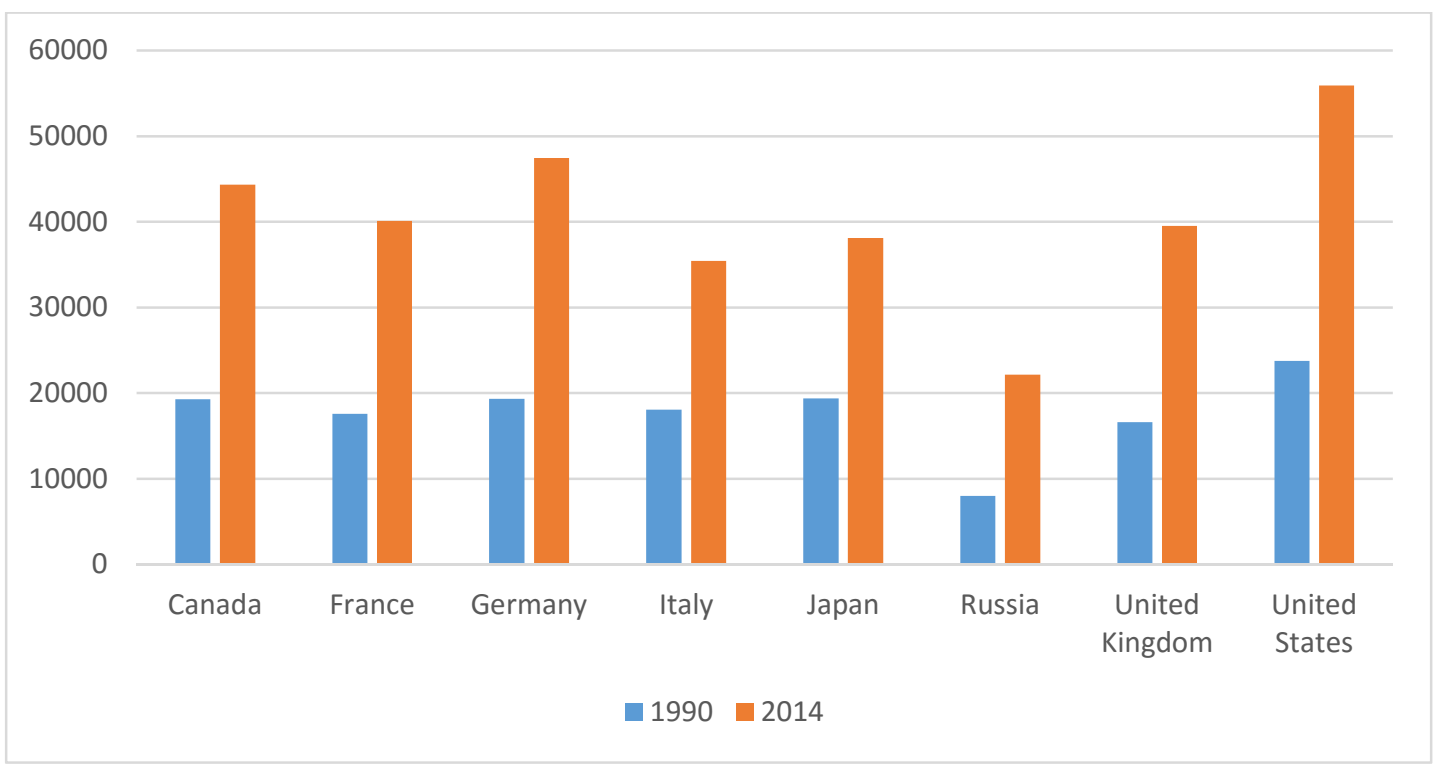

Source: World Bank, World Economic Indicators.

The picture changes when we look at incomes per hour worked rather than incomes per capita (Chart 2). The Conference Board data on incomes per hour worked, produced by a team led by Professor Angus Maddison at Groningen University in the Netherlands, have become available only in recent years for a significant number of countries. The measure of hours used is hours actually worked, including paid overtime and not including paid hours not worked due to sickness, holidays, and so on. The data show that American workers put in more hours of work (1,800 per year in 2014) than workers in Europe (1,700 in Italy and the UK, 1,500 in France, 1,400 in Germany). Further, because European workers retire earlier than American workers, among other things, labor force participation rates are higher in the US (63\%, as in the UK) than on the European continent (60\% in Germany, $56 \%$ in France, $49 \%$ in Italy).

Why do Americans work longer hours and retire later than many Europeans? One likely reason is that many Americans lack the social security that Europeans take for granted. The picture is complicated slightly, however, by the fact that unemployment is lower in the US ( $6 \%$ in 2014, as in the UK) than in parts of the European continent (10\% in France, $12 \%$ in Italy but $5 \%$ in Germany). 


\section{Chart 2. G8 countries: GNI per hour worked 1990 and 2014 (2015 USD, ppp)}

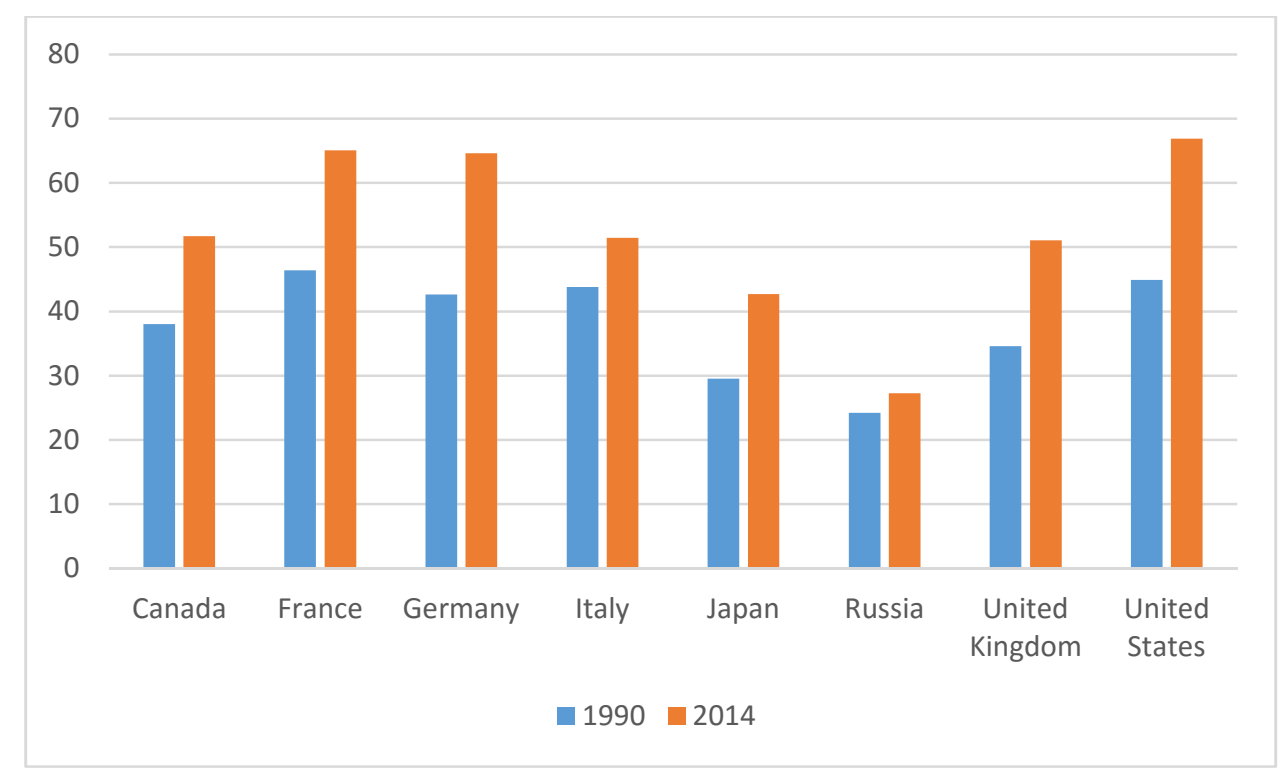

Source: The Conference Board Total Economy Database ${ }^{\mathrm{TM}}$, May 2016.

In Chart 2, GNI per hour worked $y$ is defined as

$$
y=\frac{Y}{H}=\frac{\frac{Y}{Q}}{\left\{\left(\frac{H}{E}\right)\left(\frac{E}{L}\right)\left(\frac{L}{Q}\right)\right\}}
$$

Here $Y$ is GNI, $H$ is hours worked, $Q$ is population, $E$ is employment, $L$ is labor force, and $E / L=1-u / 100$ where $u$ is the unemployment rate in percent. The labor force participation rate is $L / Q$. Chart 2 shows how France and Germany reach virtual parity with the US when economic performance is measured by income per hour worked $y=Y / H$ rather than by income per person $Y / Q$. Further, Italy rises from $63 \%$ of the US level in Chart 1 to $77 \%$ in Chart 2 while the UK rises from $71 \%$ to $76 \%$.

\section{Adjusting for education and health: Example from Italy}

We make two further adjustments to acknowledge the limitation that income per hour worked, like GNI per capita, is a one-dimensional measure. Before adjusting the figures in Chart 2 for inequality, let us briefly look at the adjustments for education and health made 
in the Human Development Index.

The $H D I$ is a three-pronged measure weighing together income per person, education, and health in equal proportions as follows

$$
H D I=\sqrt[3]{\left(I_{\text {Income }}\right)\left(I_{\text {Education }}\right)\left(I_{\text {Health }}\right)}
$$

Each of the three component indices under the cubic root is defined as

$$
I=\frac{\text { Actual value }- \text { Minimum value }}{\text { Maximum value }- \text { Minimum value }}
$$

First, per capita income is measured by the natural log of actual per capita GNI minus $\ln (100)$ divided by $\ln (75,000)$ minus $\ln (100)$ where USD 75,000 is the assumed maximum value of per capita GNI and USD 100 is the assumed minimum value. The logs are used to represent the diminishing marginal utility of transforming income into wellbeing, the point being that an increase of per capita GNI by USD 100 in a country with an average income of USD 500 has a greater impact on the standard of living than the same USD 100 increase in a country where the average income is USD 5,000 or USD 50,000. For Italy, for example, where income per capita was USD 33,030 in 2014 in 2011 USD at PPP, this formula gives

$$
I_{\text {Income }}=\frac{\ln (33,030)-\ln (100)}{\ln (75,000)-\ln (100)}=\frac{10.405-4.605}{11.225-4.605}=0.873
$$

Second, education is measured in two different ways, by mean years of schooling for adults aged 25 years and more (a backward-looking measure ranging from 0 to 15 years) and expected years of schooling for children of school entering age (a forward-looking measure ranging from 0 to 18 years). Each index is computed using the above formula involving actual, minimum, and maximum values and then the arithmetic average of the two is taken to produce a value for $I_{\text {Education. }}$ For Italy, this gives 


$$
\begin{gathered}
I_{\text {Mean years }}=\frac{10.1-0}{15-0}=\frac{10.1}{15}=0.673 \\
I_{\text {Expected years }}=\frac{16.0-0}{18-0}=\frac{16.0}{18}=0.889
\end{gathered}
$$

and hence

$$
I_{\text {Education }}=\frac{0.673+0.889}{2}=0.781
$$

Third, health is assessed by life expectancy at birth with a minimum value of 20 years, derived from historical evidence showing that no country in the 20th century had a life expectancy of less than that, and a maximum value of 85 years. For Italy, whose life expectancy at birth has risen to 83.1 years, second only to that of Japan with 83.5 years, this gives

$$
I_{\text {Health }}=\frac{83.1-20}{85-20}=\frac{63.1}{65}=0.971
$$

Taking a geometric average of the three component indices, the HDI for Italy is found to be

$$
H D I=\sqrt[3]{(0.873)(0.781)(0.971)}=0.873
$$

Notice how, in Italy, education tends to lower the score while health tends to raise it, making the HDI, by coincidence, equal to Income.

\section{Adjustment for inequality}

The next step is to extend the HDI by adjusting it to include measures of inequality. The method is straight-forward. The inequality-adjusted $H D I$ is defined as a geometric average of three component indices as before 


$$
\begin{gathered}
H D I^{a d j}=\sqrt[3]{\left[\left(I_{\text {Income }}\right)\left(1-A_{\text {Income }}\right)\right]\left[\left(I_{\text {Education }}\right)\left(1-A_{\text {Education }}\right)\right]\left[\left(I_{\text {Health }}\right)\left(1-A_{\text {Health }}\right)\right]} \\
=\sqrt[3]{\left(1-A_{\text {Income }}\right)\left(1-A_{\text {Education }}\right)\left(1-A_{\text {Health }}\right)} H D I
\end{gathered}
$$

Each of the adjustment terms $1-A$ reduces the contribution of the variable in question (income, education, health) to a degree that reflects the inequality of the distribution of each variable across the population. With some simplification, the HDI team defines each adjustment factor $1-A$ as the ratio between the geometric and arithmetic means of the relevant distributions. These inequality adjustments do affect the rankings. Chart 3 shows how the US drops from a first-place tie with Canada and Germany based on the unadjusted $H D I$ (blue columns) to the second lowest ranking based on the inequality-adjusted HDI, followed only by Russia (red columns). The US rank drops 20 places when the HDI is adjusted for inequality, from 8 to 28, while France's rank remains unchanged at 22 . Germany also remains unchanged at 6 while Italy drops one point from 27 to a tie with the US at 28.

Chart 3. G8 countries: HDI and inequality-adjusted HDI 2014

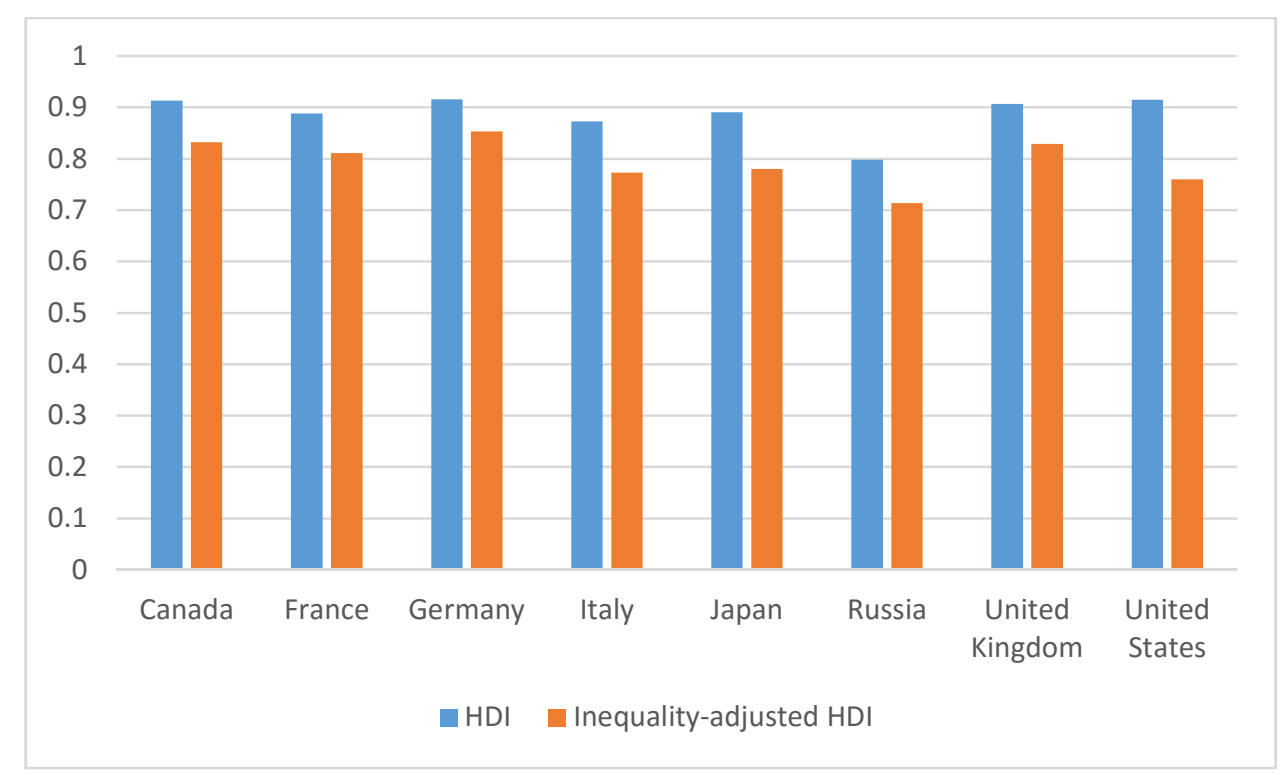

Source: United Nations Development Program.

While these adjustments for education, health, and equality constitute welcome improvements, we now apply the inequality adjustment proposed by the HDI team to the 
Conference Board data on GNI per hour worked, $y$. Following the Human Development Index, income per hour worked adjusted for inequality can be defined as

$$
y^{a d j}=y(1-G i n i)
$$

compressing two dimensions into one. This adjustment is similar to using $1-A$ in the computation of $H D I^{\text {adj }}$ above. The Gini index is closely correlated with other standard measures of dispersion such as the standard deviation of incomes around the mean, the ratio of the geometric mean of the income distribution to its arithmetic mean, the Palma ratio (the ratio of the share of the richest $10 \%$ of the population in GNI divided by the share of the poorest $40 \%$ ), and the $20 / 20$ ratio (the ratio of the share of the richest $20 \%$ of the population in GNI divided by the share of the poorest 20\%). If the Gini index equals 0 , there is perfect equality and no need for adjustment so $y^{a d j}=y$ whereas if Gini equals $1 y^{\text {adj }}$ collapses to zero. But these are unrealistic extreme values. Generally, a Gini index between 0.2 and 0.3 as in Scandinavia is viewed as a sign of a reasonably equal distribution of income, an index between 0.3 and 0.4 as in Italy with Gini $=0.35$ is regarded as middle of the road, and an index above 0.4 as in Russia and the US is viewed as a sign of significant inequality in the distribution of income. Further research is needed to ascertain whether there is a tendency for large countries to be less egalitarian than small countries just as, for example, big cities in the US appear to have less equally distributed incomes than the rest of the country (Berube, 2014).

Chart 4 tells the story by showing GNI per hour worked and inequality-adjusted GNI per hour worked in 2014 side by side based on the HDI team's measure of income inequality which differs slightly from their Gini index for 2005-2013 (UNDP, 2015) and also from the most recent Gini indices reported by the World Bank. Without the adjustment for inequality (blue columns), the US leads the pack, barely beating France and Germany as we saw in Chart 2. With the inequality adjustment in place (red columns), however, the US falls into third place, following Germany and France even if it remains slightly ahead of the UK, Canada, Italy and Japan as well as, of course, Russia. Consideration of inequality of income makes a difference. 


\section{Chart 4. G8 countries: GNI per hour worked and inequality-adjusted GNI per hour worked 2014 (2015 USD, ppp)}

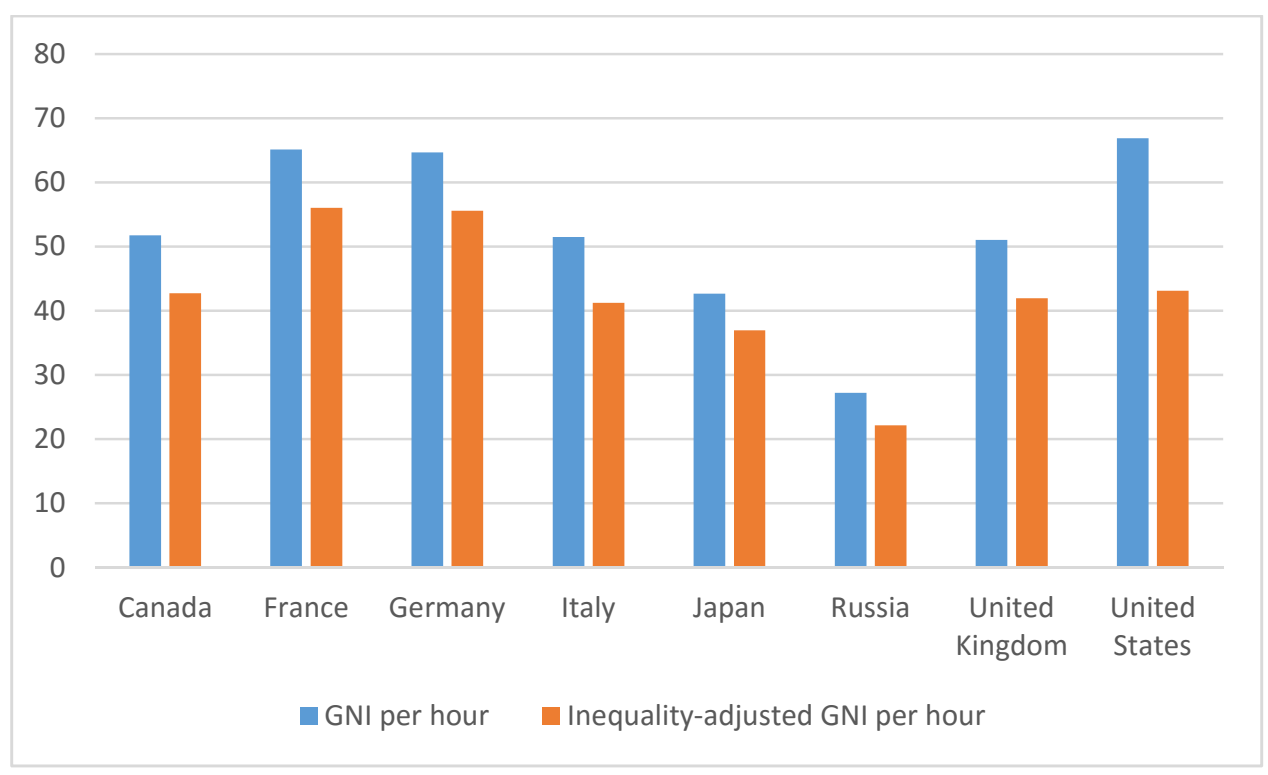

Source: Author's computations based on sources behind Charts 1 and 2 .

Note: The blue columns in Chart 4 are the same as the red columns in Chart 2.

\section{Adjusting the HDI for hours worked}

At last, we combine the adjustments for hours worked suggested here and those proposed by the HDI team, in three steps. First, we compute an index for income per hour worked, replacing $I_{\text {Income }}$ by $I_{\text {Hour }}$ where the maximum and minimum values for income per hour are assumed to be USD 100 and USD 2, the lowest such number on record at present. Second, we compute $I_{\text {Hour }}\left(1-A_{\text {Hour }}\right)$ where $A_{\text {Hour }}$ is taken to be the same as $A_{\text {Income }}$. Third, we replace Income $\left(1-A_{\text {Income }}\right)$ by $I_{\text {Hour }}\left(1-A_{\text {Hour }}\right)$ in the formula for $H D I^{\text {adj }}$ to arrive at an estimate of an HDI doubly adjusted for inequality as well as for hours worked. Chart 5 shows that adjustment for hours and inequality as well as for education and health relegates the US to seventh place among the G8 countries, ahead only of Russia, in terms of an inequalityadjusted HDI weighing together income, education attainment, and life expectancy and relying on the purchasing power of income per hour worked rather than of income per capita in computing the income component. These considerations dramatically change the relative positions of the countries. 


\section{Chart 5. G8 countries: Inequality-adjusted HDI, also adjusted for hours worked 2014 (2015 USD, ppp)}

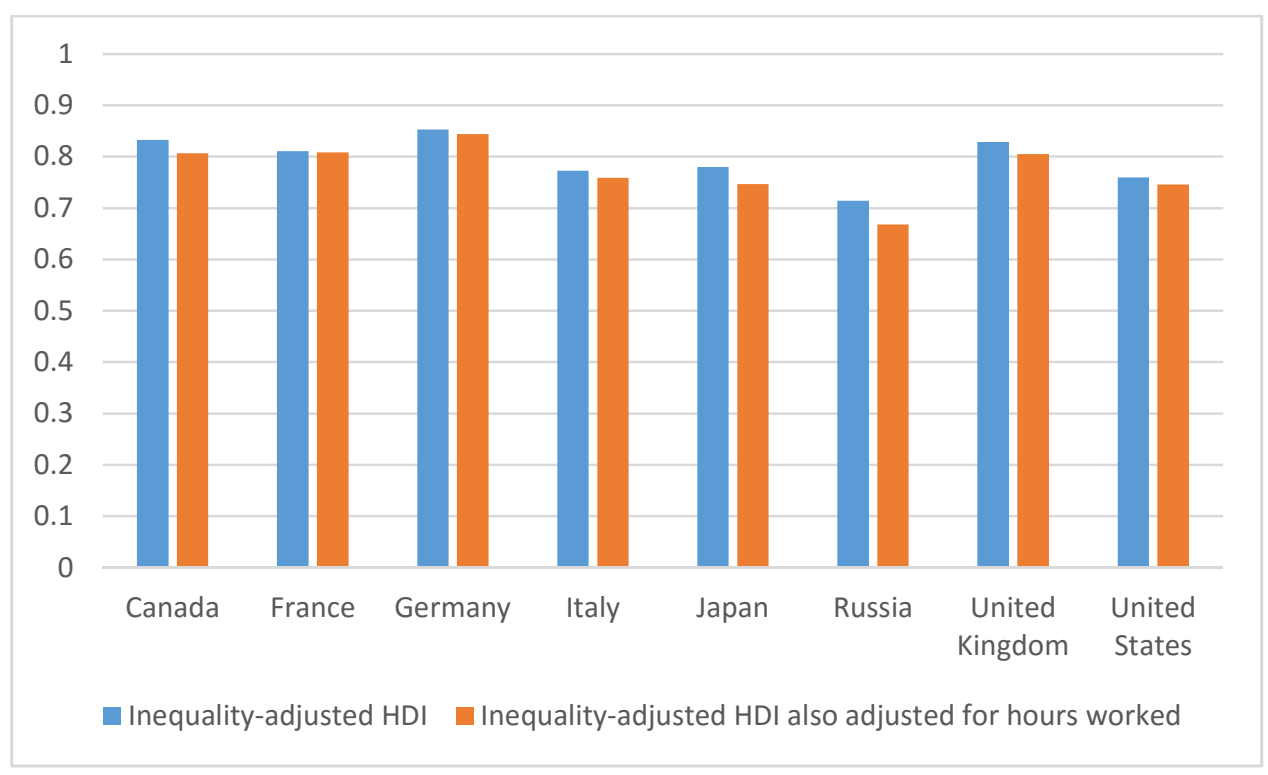

Source: Author's computations based on sources behind Charts 1-3.

Against this background, we now turn to discussing the European Union with its many small Member States and their emphasis on social measures and equity and how it compares with the United States.

\section{The European Union's Successful Widening1}

Recent significant troubles notwithstanding, I see three main reasons why the EU deserves to be regarded as a brilliant success: Peace, prosperity, and democracy.

\section{The EU's soft power}

First, the EU has helped keep the peace among its members since 1945, the longest continuous period of peace and harmony among them since time immemorial. Chancellor Helmut Kohl, one of the chief architects of German reunification as well as of European unification, put the matter well when he declared that Germany wanted to share her sovereignty and her fate with her European neighbors so that they never again need to fear

\footnotetext{
1 This section draws on and updates Gylfason (2016).
} 
German belligerency.

Second, the EU has promoted prosperity on the continent by facilitating a major economic and social transformation with an unwavering emphasis on human rights. European cities from Helsinki to Lisbon - and, yes, also from Athens to Dublin - have been transformed before our eyes, and the same applies to the European countryside. The EU's strong emphasis on human rights has involved, among many other things, the abolition of the death penalty throughout the union membership. The Americans have taken notice: the number of death sentences and executions in the United States has dropped significantly since the mid-1990s (Amnesty USA, 2016).

Third, the EU's emphasis on democracy as a prerequisite for accession has encouraged the people of formerly autocratic countries to throw off long-standing dictatorships. Only then would the EU welcome them back into the European fold. Greece (1981), Portugal and Spain (both 1986) in Southern Europe were admitted, and the eight former communist countries in East and Central Europe in 2004 and 2007 along with Malta and Cyprus enlarging the EU, making Europe whole and free. Thus far, only Iceland, Norway, and Switzerland have opted to stay outside the Union.

Several neighboring countries still aspire to membership (Albania, Macedonia, Montenegro, Serbia, and Turkey). Catalonia is eager to join - or rather, remain in - the EU, as is Scotland, after achieving independence. About a half of the Catalan population wants independence from Spain because many of them feel treated like a minority within Spain lacking full respect and full rights. The government in Madrid threatens to keep an independent Catalonia outside the EU, a threat that contradicts the EU's open-arms policy and is, therefore, likely to prove empty. The Scottish situation is different. There, also, about a half of the voters still want independence, primarily because they want Scotland to be more like Scandinavia, thus setting England free. Scotland joined the United Kingdom in 1707 primarily to gain access to a much larger market. Today, as part of the EU, Scotland enjoys such access and, therefore, does not any longer need to be part of the UK for reasons of trade even if most of Scotland's trade is still with England. The threat from Westminster - and from Madrid! - that Scotland will lose its EU membership if it leaves the UK sounds hollow because, again, it is incompatible with the EU's open-arms policy. The threat from Westminster appears also a bit comical in view of the fact that the Conservative 
government held an advisory referendum in which a small majority of the voters expressed their wish to leave the EU, a result that triggered instant demands for immediate Scottish independence to enable Scotland to remain in the EU. Northern Ireland and perhaps also Wales may want to think again.

In both Catalonia and Scotland, the prospect of continued EU membership holds the key to independence. Without membership, many of those who advocate independence would have doubts as they would fear weakened trade relations. As members, however, Catalonia and Scotland would have continued access to Spanish and perhaps also English markets through the EU even after England and Wales leave the EU.

\section{Efficiency and fairness in a union of small European states}

With time, the character of the EU has changed as it has developed toward a union of small European states. Small states tend to be more homogeneous and more cohesive than large, i.e., populous states (Alesina and Spolaore, 2003). This helps to explain why income inequality in the US is greater than in Europe and why the EU membership of more small countries is likely to cement the EU's emphasis on equality and fairness. The World Happiness Report, based on people's own reports of the quality of their lives, suggests that small can be beautiful. Of the 25 happiest countries 2013-2015, twenty are small or medium-sized (Helliwell, Layard, and Sachs, 2016, Fig. 2.2). The five exceptions are the US (rank 13), Germany (16), Brazil (17), Mexico (21), and the UK (23). The other G8 countries line up thus: Canada 6, France 32, Italy 50, Japan 53, and Russia 56. The Bertelsmann Sustainable Development Goals Index, derived from a holistic sustainable development approach incorporating economic, social, and environmental objectives, conveys a similar impression (Kroll, 2015). Of the top 25 countries deemed most ready to achieve the sustainable development goals set by the UN, all but seven are small or medium-sized. The seven exceptions are Germany (rank 6), France (10), Japan (13), UK (15), Spain (18), Poland (21), and Korea (23). The other G7 countries line up thus: Canada 11, Italy 26, and US 29 (Russia is not included among the 34 countries covered).

If an independent Catalonia joins the EU, it will become the typical EU member in terms of population size. Of the 29 members, there will be 15 countries larger than Catalonia and 13 smaller ones. This shows how unreasonable it is to maintain that Catalonia or Scotland 
are too small to stand on their own feet as sovereign EU members. Denmark and Finland are the size of Scotland and smaller than Catalonia. Denmark has been an EU member since 1973 as well as a de facto subscriber to the euro and Finland has been a member of the EU as well as of the Economic and Monetary Union (EMU) since 1994. If Denmark and Finland were able to do so well by their EU membership, there can be no reasonable doubt about the ability of Catalonia and Scotland to do the same. Europe is a continent of regions.

With more small members on the horizon, the common interests of small countries will weigh more heavily in EU policy making and institutions. Clearly, Europe has its political disagreements separating left from right, north from south, east from west, and so on, as does the US and other countries. Even so, Europe's advanced social model faces no serious challenge within Europe. This makes Europe quite different from the US where the more limited and less ambitious welfare state legislation launched by Democratic Presidents Franklin D. Roosevelt, John F. Kennedy, and Lyndon B. Johnson and culminating in Obamacare at present is under fierce attack by its Republican opponents in Congress, a situation that seems less thinkable in Europe.

The strong parallel emphasis on efficiency and fairness is, as I see it, the key to the economic and social advances accomplished thus far by the EU. This helps to explain the continued attractiveness of EU membership to all but the most inward-looking countries in Europe. Further, the minority of voters against EU membership within individual countries includes European advocates of the US Republican extremism that now, with the 2016 US presidential election approaching, threatens the cohesion of the Republican Party.

\section{Europe vs. the US}

The weaknesses that have emerged in modern America - lack of trust, political gridlock, stagnant wages for the average worker, and increased inequality - mirror the strengths of the European model. In his seminal book Bowling Alone, Robert Putnam (2000) charted the collapse of trust in American society, a gradual process the way Putman describes it.

Let me suggest three related phenomena to highlight some of the current differences between the US and Europe.

- American workers spend 1,800 hours per year at work compared with 1,400 hours in Denmark and Germany, 1,500 in France, 1,600 in Sweden and Switzerland, and 1,700 in 
Italy and the UK (Conference Board, 2015). As suggested before, one plausible explanation for these differences is that US workers need to put in long hours to compensate for the lack of social security that Europeans have long been able to take for granted (Gylfason, 2007). Europeans have seen their economic wellbeing rise through higher incomes as well as through relatively more leisure and less work.

- In 1960, the average American was 2-3 cm (1 inch) taller than the average German. Today, the average German is $2-3 \mathrm{~cm}$ taller than the average American as documented in a series of works by John Komlos and his associates where they include only native-born Americans who speak English at home, screening out people of Asian and Hispanic descent (see, e.g., Komlos and Baur (2004) and Komlos and Lauderdale (2007)). Why? A likely reason for this reversal seems to be that tens of millions of US citizens, children in particular, have been left behind, in poverty and without adequate social insurance, unable to attain normal physical stature, thereby dragging down - or, more precisely, slowing down the natural advance of - the average height of the adult population in the US (Gylfason, 2007). If this interpretation is correct, it constitutes a strong case against pronounced inequality of incomes and wealth on economic grounds apart from the ethical issues at stake as well as strengthening the case for assessing economic performance in terms of both the level and distribution of national income. Even so, this hypothesis must not be taken too far. Angus Deaton (2007, 1), noting that "adult African women are taller than is warranted by their low incomes and high childhood mortality," concludes that "The relationship between population heights and income is inconsistent and unreliable, as is the relationship between income and health more generally."

- With Anne Case, Deaton has shown that middle-aged non-Hispanic white Americans have faced declining life expectancies since 1999 due to a sharp rise in life-style related diseases and suicides (Case and Deaton, 2015). Declining life expectancies are unheard of in modern times except in Russia after the collapse of communism and in Africa due to public health disasters, especially the HIV/AIDS epidemic. The lives thus lost in the US are almost as many as those lost to the HIV/AIDS epidemic since 1981 ( 0.5 million vs. 0.65 million). On average, except for Russia, Europeans live two to four years longer than Americans. 


\section{Difficulties}

There is no denying that the EU presently faces serious difficulties, some of its own doing, some not, including the recent stream of Syrian and other refugees into the EU. While the EU cannot be blamed for the influx of refugees, the EU bears itself some of the blame for some of its other current problems. The EU has looked the other way while anti-democratic tendencies have intensified in Hungary and, more recently, also in Poland. The EU could have reacted by, for example, imposing economic sanctions - say, by withdrawing financial support from Hungary - but chose not to do so. Likewise, the EU seems not to have done much to try to rein in rampant corruption in Greece, Bulgaria, and Romania. The economic troubles of Greece can be said to follow in part from the EU's flawed fiscal and financial architecture, a problem well understood from the inception of the euro but one which the EU institutions have yet to address satisfactorily. This list includes, among other things, a misplaced and costly emphasis on economic austerity promulgated by Germany. In view of these issues, it is understandable that some older EU members are inclined to think that now is a good time to slow down the geographic expansion of the EU by sharpening the focus on deepening European integration while putting widening on hold for the time being. Even so, the EU would benefit from the admission of new members such as deeply democratic Catalonia and Scotland. This would lend an even stronger voice to advocates of the EU as a union of small European states eager to advance economic efficiency and social justice side by side.

Much has been made recently of Greece's impossibility to overcome her financial predicament by devaluing her currency. Some argue that macroeconomic adjustment by other means within the confines of the euro is bound to be more costly than devaluation of the drachma would have been. This may well be true as far as it goes. Even so, several euro countries have managed a significant adjustment in recent years, including Ireland, Portugal, and Latvia where, in 2014, unemployment was in the range between $11 \%$ and $14 \%$ of the labor force compared with $26 \%$ in Greece. In 2007, all four countries had unemployment rates between $5 \%$ and $8 \%$. The experience of Ireland, Portugal, and Latvia shows that adjustment by other means sometimes referred to as an internal devaluation fiscal restraint, wage cuts, and more - with the euro in place is possible despite protracted 
pain. None of these countries seriously considered leaving the euro zone, nor did Greece. Comparisons of the euro with the Gold Standard are misplaced because the euro floats: the European Central Bank can devalue the euro vis-à-vis other currencies through monetary policy actions if it wants to.

\section{Iceland's Attitude Toward the EU}

Iceland became a founding member of NATO in 1949. The decision to join was not based on detailed benefit-cost analysis. Details did not matter. Rather, the Icelandic parliament decided that NATO is a club where Iceland belongs. In other words, Iceland's parliament decided to share Iceland's fate with that of other members of the alliance, including most of Iceland's closest friends and allies. No referendum was held.

\section{Membership application in 2009}

The Icelandic parliament's decision to apply for EU membership in 2009 was not based on an explicit benefit-cost analysis. The principle is the same as before: those in favor of membership view the EU as a club where Iceland belongs if only because all of our closest allies except Norway are members. I personally believe Iceland should join the EU even if it could be demonstrated that the economic costs of membership outweigh the economic benefits because there are also important political benefits, impossible to quantify.

From the early 1990s until the financial crash of 2008 opinion polls showed that Icelandic voters were consistently albeit marginally in favor of EU membership whereas political parties, subservient to the oligarchs they had created by granting them virtually

free access to Iceland's valuable fish resources, and powerful interest organizations stood shoulder-to-shoulder against membership. Here the situation was diametrically opposite to that of Norway. With its back to the wall after the financial crash, Iceland filed an application for membership in 2009. The application could be understood as a way of saying to the rest of Europe: Please excuse us for having permitted our banks to separate you from so much of your cash, but we are now prepared to abide by the discipline required by EU membership. With the political parties held primarily responsible for pushing Iceland off the cliff in 2008 through their crony privatization of the banks during 
1998-2003 back in power in 2013, they attempted to withdraw the application in 2015 as if to say: We did not really mean to say we are sorry.

This is, however, a controversial interpretation. While many Icelanders apparently felt a collective guilt about having voted for politicians who through the corrupt privatization of the banks paved the way toward the abyss in 2008, others had no such feelings of guilt, blaming the crash on bankers or politicians or even on alleged foreign conspirators, including the EU, the IMF, and the governments of the other Nordic countries whose tax payers financed more than a half of the IMF-supported USD 5 billion rescue operation. Anyhow, the attempt in 2015 to withdraw the EU membership application may not have succeeded in full even if Iceland is no longer on the EU's official list of applicant countries. Specifically, parliament put in the membership application in 2009 whereas the foreign minister, not parliament, attempted to pull out unilaterally in 2015, a pullout that can be considered invalid by the EU on the grounds that an individual minister or the government cannot undo a formal decision by parliament. Hence, as the European Commission (2016) has let it suffice to say that "in March 2015 Iceland's government requested that "Iceland should not be regarded as a candidate country for EU membership,"'” Iceland's application is probably best viewed as remaining on hold, waiting to be reactivated by a new parliament which will then put the negotiated membership agreement before a national referendum as promised by parliament and as required by the new constitution that was accepted by $2 / 3$ of the voters in 2012 and awaits ratification by parliament.

The distinction between an application on hold and a withdrawn application is a crucial one because a new applicant country needs unanimous acceptance by the European Council comprising the heads of state of all EU members. Thus, if the attempt by Iceland's foreign minister to withdraw Iceland's 2009 application had succeeded, a new parliament would have to secure anew the approval of each individual EU member. The foreign minister was, in other words, trying to tie the hands of future parliaments. In view of this key point it is hard to understand why Switzerland decided in June 2016, without any external encouragement, to withdraw its application for EU membership that has lain dormant since 1992 when the Swiss voters rejected membership in the European Economic Area. 
Recent developments in Greece, Ireland, and Spain make Icelandic accession to EU membership a harder case to sell. This helps to explain why public opinion has swung against membership since 2008 even if developments in Baltic and Balkan countries suggest a different conclusion. Estonia, Latvia, and Lithuania joined the EU in 2004 and by now all three use the euro. Croatia became the EU's 28th member in 2013, ten years after filing its membership application. Undeterred by events in Greece, Albania became an official candidate for accession to the EU in 2014. Bosnia and Herzegovina applied for membership in 2016 but has not yet been added to the list of candidate countries.

Another important reason for the change in public sentiment in Iceland concerning EU membership is that some Icelandic politicians tried to deflect their own responsibility for Iceland's home-made crash by blaming it on foreigners and whipping up immigrantunfriendly chauvinism in Icelandic politics for the first time in history. In terms of economic damage relative to national economic output as well as in terms of fiscal costs, Iceland's financial crash in 2008 crash was among the greatest ever recorded (Laeven and Valencia, 2012). For example, the damage inflicted on foreign creditors and shareholders was greater than anywhere else relative to the size of the Icelandic economy.

\section{Benefits still missing}

What would be the main benefits and costs of EU membership? The economic benefits are clear even if European Economic Area membership from 1994 has delivered many of them already. Yet, several significant benefits are still missing.

- Many Icelanders see the adoption of the euro as a key benefit in view of Iceland's poor record of monetary management which has allowed the Icelandic króna to lose 99.95\% of its value vis-à-vis the Danish krone since 1939. Apart from the general philosophy behind the EMU, small countries can benefit from outsourcing the least successful parts of their national policy-making apparatus - such as monetary policy in Iceland's case just as they should resist outsourcing their most successful procedures. Glick and Rose (2016) report that the EMU has boosted exports by about $50 \%$.

- The Common Agricultural Policy is far less expensive for Europe's consumers and tax payers than is domestic farm protection in Iceland as has always been the case. Thus, 
while producer support in the EU decreased from 39\% of gross farm receipts in 1986 to $18 \%$ in 2014 , it decreased from $76 \%$ to $48 \%$ in Iceland during the same period (OECD, 2015).

- In view of Iceland's checkered history of oligopolies and lack of competition in a number of areas, including agriculture, banking, fisheries, and trade, the EU's Competition Policy and associated monitoring and surveillance could offer significant benefits to Iceland. More competition and more trade would increase welfare. Banks from Denmark and Sweden next door operate branches in Norway, but not in Iceland.

- The Common Fisheries Policy constitutes a problem for Iceland, however, that needs to be solved. Iceland needs to understand and respect that the EU was built on the fundamental premise of the original European Coal and Steel Community of 1953 stipulating joint management of Europe's natural resources. At the same time, the EU needs to understand Iceland's significant dependence on her fisheries - a dependence that concerns the national economy of Iceland as a whole and not just local fishing communities as in the rest of Europe. The EU's toleration of inefficient fisheries policies, tacitly justified by viewing fisheries as a fairly unimportant regional concern, cannot be accepted in Iceland where fishing remains a macroeconomic concern. Even so, Iceland needs a major overhaul of its fisheries management regime which the Supreme Court of Iceland ruled discriminatory and hence unconstitutional in 1998, a verdict confirmed by the United Nations Human Rights Committee in 2007 (Gylfason, 2009a). In the national referendum on a new post-crash constitution for Iceland, $83 \%$ of the voters declared support for a provision stipulating national ownership of natural resources, including full charge for the right to fish in Icelandic waters in keeping with the user-pays principle of environmental policy now openly advocated by the World Bank and the IMF as the best way to deal with climate change (Lagarde and Yong Kim, 2015). Whereas Norwegian tax payers have been able to claim about $80 \%$ of Norway's oil rent from the outset, $90 \%$ of the fisheries rent in Iceland still acrues to the vessel owners - Iceland's answer to Russia's oligarchs (Thorláksson, 2015). 


\section{Conclusion}

Small can be beautiful. On average, around the world, small countries tend to have higher per capita incomes than large countries because various benefits of small size, including cohesion and homogeneity, seem to outweigh the diseconomies of small scope and scale and small pools of talent (Alesina and Spolaore, 2003; Gylfason, 2009b). Further, it is possible that small countries tend to be more egalitarian than large countries. For both of these reasons, the EU can expect to benefit from welcoming more small states as members. National boundaries matter less and less when cross-border trade is free. This is why the independence aspirations of Catalonia, Scotland, the Faroe Islands, and others need not be viewed with alarm. Europe is a continent of many regions. Along European lines, illdesigned national boundaries outside Europe would be easier to rearrange if trade were free as in Europe, supported by social efficiency, freedom, fairness, and respect for human rights. 


\section{References}

Alesina, Alberto, and Enrico Spolaore (2003), The Size of Nations, MIT Press, Cambridge, Massachusetts.

Amnesty USA, http://www.amnestyusa.org/our-work/issues/death-penalty/us-deathpenalty-facts/death-penalty-trends, accessed 8 July 2016.

Berube, Alan (2014), “All Cities Are Not Created Unequal," Metropolitan Opportunity Series No. 51, Brookings Institution, Washington, DC.

Case, Anne, and Angus Deaton (2015), "Rising Morbidity and Mortality in Midlife Among White Non-Hispanic Americans in the 21st Century," PNAS, National Academy of Science.

Conference Board (2015), The Conference Board Total Economy Database, accessed 8 July 2016.

Daily Telegraph, 21 April 2016, http://www.telegraph.co.uk/news/2016/04/21/as-yourfriend-let-me-tell-you-that-the-eu-makes-britain-even-gr/, accessed 8 July 2016.

Deaton, Angus (2007), “Height, Health, and Development," PNAS, National Academy of Science, August 14, Vol. 104, No. 33.

Deaton, Angus (2013), The Great Escape: Health, Wealth, and the Origins of Inequality, Princeton University Press, Princeton and Oxford.

European Commission, http://ec.europa.eu/economy finance/international/enlargement/index en.htm, accessed 8 July 2016.

Feige, Edgar L. (1979), “How Big Is the Irregular Economy?,” Challenge, NovemberDecember, Vol. 22, No. 5, 5-13.

Glick, Reuven, and Andrew K. Rose (2016), “Currency Unions and Trade: A Post-EMU Reassessment," European Economic Review, Vol. 87, August, 78-91.

Gylfason, Thorvaldur (2007), "Why Europe Works Less and Grows Taller," Challenge, January-February, 21-39.

Gylfason, Thorvaldur (2009a), "Hvað segja lögin: Sameignarauðlindir eru mannréttindi" (What Does the Law say? Common Property Resources as Human Rights) in Ragnarsbók (Festschrift for Ragnar Aðalsteinsson), Icelandic Literary Society, Reykjavík, 497-522. 
Gylfason, Thorvaldur (2009b), “Is Iceland Too Small?" VoxEU.org, 19 August.

Gylfason, Thorvaldur (2016), “The EU's Open Arms and Small States," Nordicum-

Mediterraneum: Icelandic E-Journal of Nordic and Mediterranean Studies.

Helliwell, John, Richard Layard, and Jeffrey Sachs (eds.) (2016), World Happiness Report, http://worldhappiness.report/wp-content/uploads/sites/2/2016/03/HR-V1 web.pdf, accessed 9 July 2016.

Komlos, John, and Marieluise Baur (2004), "From the Tallest to (One of) the Fattest: The Enigmatic Fate of the American Population in the 20th Century," Economics and Human Biology, Vol. 2, No. 1, March, 57-74.

Komlos, John, and Benjamin E. Lauderdale (2007), "The Mysterious Stagnation and Relative Decline of American Heights after c. 1960," Annals of Human Biology Vol. 43, No. 2, March-April, 206-15.

Kroll, Christian (2015), Sustainable Development Goals: Are the Rich Countries Ready?, Bertelsmann Stiftung, Berlin.

Lagarde, Christine, and Jim Yong Kim (2015). "The Path to Carbon Pricing," Project Syndicate, 19 October.

Laeven, Luc, and Fabián Valencia (2013), “Systemic Banking Crises Data Base," IMF

Economic Review, Vol. 61, 225-270.

OECD (2016), Agricultural Policy Monitoring and Evaluation 2015, OECD, Paris.

Putnam, Robert (2000), Bowling Alone, Simon and Schuster, New York.

Schneider, Friedrich (2007), "Shadow Economies and Corruption All Over the World: New

Estimates for 145 Countries," Economics: The Open-Access, Open-Assessment E-Journal, July, Vol. 1, No. 2007-9, 1-66.

Schneider, Friedrich, and Dominik Enste (2000), "Shadow Economies: Size, Causes, and Consequences," Journal of Economic Literature, Vol. 38, No. 1, 77-114.

Stiglitz, Joseph E., Amartya Sen, and Jean-Paul Fitoussi (2010), Mismeasuring Our Lives: Why GDP Doesn't Add Up, The Report by the Commission on the Measurement of Economic Performance and Social Progress, The New Press, New York.

Thorláksson, Indridi H. (2015), "Veiðigjöld 2015. Annar hluti” (Fishing Fees 2015. Part Two).

United Nations Development Program (2015), Human development Report. 
World Bank (2006), Where Is the Wealth of Nations? Measuring Capital for the 21st Century, Washington, D.C. 